\title{
THE RECOLLECTIONS OF A MOVEMENT: MEMORY AND HISTORY OF THE NATIONAL ORGANIZATION OF PEOPLE'S COLLEGES
}

\author{
DINI METRO-ROLAND \\ Indiana University, Bloomington, IND, \\ USA
}

Today, with the full benefit of hindsight, it would be redundant to write about the inevitability of the Stalinization of Hungary in the post World War II period. But to those who lived through this tumultuous time, it was a period replete with contradiction and uncertainty, when even the most astute political thinkers, such as István Bibó, were unable to predict what was to come. This work will explore Hungary's postwar period through the looking glass of the history and memory of NÉKOSZ, the National Organization of People's Colleges, a short-lived youth movement in postwar Hungary that fell victim to political purges but remains alive today in the memories of many of its participants.

The work will be divided into two main parts based on two different methodologies employed. The first part will contain a traditional narrative history of the movement in which I will trace the ideological origins and development of the movement, describe how NÉKOSZ contributed to the Stalinization of the country, and recount its demise in the Stalinist purges and the unsuccessful campaign for its return. This half will emphasize how the movement helped shape and simultaneously was itself shaped by the political events of the period. The second part will be a study of memory and the art of oral history. In this half, I will briefly describe how the movement was remembered during the Kádár period and contrast that with individual memories recorded in a series of interviews conducted in November 1999. It is hoped that this work will offer the reader a more complex picture of the period by presenting one small but significant slice of Hungarian society at a critical juncture in the transition to Stalinism.

Hungarian Studies 15/1 (2001)

0236-6568/2001/\$5.00 @ 2001 Akadémiai Kiadó, Budapest 
Hey, our banner blows in the bright winds

Hey, here it's written, Let Freedom Live!

Hey winds, blow! Bright winds, blow!

For tomorrow we will overturn the entire world!

(The NÉKOSZ anthem)

\section{Section I \\ History of a Movement}

In the late 1930s, in the wake of a new wave of Hungarian populism, a group of university students of peasant origin, under the tutelage of the ethnographer István Györffy, took part in a series of sociological studies of the peasantry. Like the village explorers, ${ }^{1}$ these students sought to present an objective picture of the stark realities of peasant life in the hope of stimulating discussion about the need to reform Hungarian society. In the course of their research, these students came into contact with an amalgam of ideologies and personalities that would have an immense impact on their lives. In addition to working in the Region and Folk Research Center [Táj- és Népkutató Központ], an institute founded by Pál Teleki, ${ }^{2}$ these students also established close ties with nationalist groups, like the Turul League, and the Populist writers, a motley crew of right and left-wing intellectuals who, like them, were committed to alleviating the plight of the peasantry. Following the death of their friend and mentor, István Györffy, the group of students decided to establish a people's college [népi kollégium]; ${ }^{3}$ a dormitory that would not only afford university students of peasant origin with food and lodging but also provide them with a forum to discuss issues of social justice and how best to fulfill the "college's moral obligation to work for the goals of the peasantry." In 1940, just one year prior to Hungary's entrance into World War II, the Bolyai People's College, later re-named the Györffy István People's College, first opened its doors.

\section{Ideology and Activism}

The original ideological makeup of the Györffy István People's College is difficult to determine with certainty. Initially, the political and ideological loyalties of these participants, or collegians [kollégisták] as they were called, seemed to be divided between their populist, nationalist, and moderate conservative sponsors and peers. Most influential was the populist ideology then propagated in a number of studies and journals dedicated to serving the peasantry. Hungarian populism colored the political worldviews of the collegians and strengthened their belief, which remained central to the movement throughout its history, that they would 
one day become members of the political elite in Hungary. "I think you are well aware", wrote collegian József Pál in a 1941 letter to his friend, "that this is the beginning of a 'silent revolution' which should not be mistaken for any fashionable trend, but might best be described as the 'second Dózsa revolution.' Its goal, the introduction of the peasantry into the axis of the administration."

Nationalist ideology also influenced the collegians during the first year. The Turul League, a right-wing nationalist youth organization that emerged in 1920 as an organ of the counter-revolutionary government, supplied the students with a building, financial backing and the juridical framework necessary to function in Hungary. Although the relationship between the two groups later became strained - the people's college broke ties with the league in 1942 - the original collegians were active Turul members and espoused many of the group's beliefs. ${ }^{6}$ More significantly, the collegians enjoyed the support of several key members of the Horthy government, such as Pál Teleki before his tragic suicide in 1941, and Ferenc Zsindely, the Minister of Trade under the Kállay government (1942-1944). ${ }^{7}$ This support proved critical following the break with the Turul League and surprising when it continued even after it became clear that the collegians had strayed considerably from the government's ideological camp.

The gradual shift leftward began in late 1941 with the emergence of a Communist cell of four collegians. Lajos Fehér, brother of the then acting principal, Gyula Fehér, arrived from Debrecen with a group of populists-turned-Communists of the March Front. ${ }^{8}$ With the help of his colleagues, Ferenc Donáth, Sándor Zöld and Géza Losonczy, ${ }^{9}$ Fehér introduced several of the collegians to the tenets of "Leninism-Marxism." 10 Within a short period of time, the influence of the Communist cell grew and it began to exert a significant influence on the other members.

In September 1942, two events further strengthened the hand of the Communists. First, following a long string of conflicts with the Turul League, the collegians proclaimed their independence and broke all ties with the League. The Ministry of Interior, at the behest of Ferenc Zsindely, not only reimbursed the people's college the entire sum lost in the break up but also granted the people's college full autonomy, unprecedented for a youth organization funded by the state. Shortly thereafter, the Communist members were able to persuade the rest of the collegians to replace the then acting principal, Lajos Horvath, with the 21 year old student László Kardos, the future architect and undisputed leader of NÉKOSZ. ${ }^{11}$ Though not yet a member of the Communist party, Kardos was the obvious choice to head the people's college. Intelligent and charismatic, Kardos transformed the loosely organized group into a well disciplined tightly-knit collective based on radical democratic principles that would form the linchpin of the people's college movement, e.g., open debate, democratic selection of leadership, and emphasis on the interests of the group over those of the individual. ${ }^{12}$ 
Kardos also convinced the collegians to be more politically active. Initially, the collegians participated in a number of small-scale anti-war demonstrations, as well as the relatively large 1941 demonstration at the gravesite of Lajos Kossuth organized by the Social Democrats' National Youth Committee. ${ }^{13}$ But as the war dragged on, the members of the Györffy People's College became progressively more radical and leftist. The number of collegians in the Communist Party more than doubled by $1943,{ }^{14}$ and in conjunction with the popular front tactics of the illegal Communist Party, the people's college formed strong ties with other leading left-wing organizations involved in the anti-war campaign. Collegians wrote articles for left-wing journals like Népszava [People's Word] ${ }^{15}$ and Szabad Szó [Free Speach], and distributed pamphlets for the Peace Party [Békepárt], the front organization of the Hungarian Communist Party.

The 1943 conference at Szárszó in which populist writers and other intellectuals gathered together to protest Hungary's participation in the war was a pivotal event in the development of the Györffy István People's College. Presaging the dilemma that would soon plague Hungary, a debate emerged during the conference between the so-called third roaders, led by László Németh, who opposed both Nazism and Bolshevism equally, and the left-wing intellectuals led by the crypto-Communist Ferenc Erdei, who, whether out of conviction or realpolitik, espoused a more radical ideology and sought to forge an alliance with Moscow. Among the proponents of the Soviet-oriented faction were László Kardos and the attending collegians. In his speech given at the conference, Kardos juxtaposed the third road with his "more developed" position, which he claimed had "already touched the truth." He invited others to join him on the "path of Sándor Petöfi," the radical poet laureate of the 1848 Hungarian revolution. He added, "Here is the opportunity for the entire Hungarian youth to demand and create with their Hungarian strength an independent, free democratic Hungary."16 By aligning themselves with Erdei, the collegians had crossed the line tolerated by the government. After the conference, Ferenc Zsindely personally berated Kardos for his speech and admonished the students about their radical activities. However, the collegians did not heed his warnings but intensified their involvement in the anti-war effort and strengthened their contact with the Communist Party. Three months later, the collegian Antal Gyenes was arrested on grounds that he was a Communist.

In a 1988 interview Sándor Györffy stated that he and most other collegians were not aware of the leadership's role in the illegal Communist Party until after Gyenes was arrested in early September 1943. "On the outside we denied it, but inside we had a feeling that the leadership was actively involved in the Communist movement, which [in our eyes] enhanced their influence." ${ }^{17}$ In the course of that year, several others were taken into custody, imprisoned and tortured for their reputed involvement in illegal Communist activities. ${ }^{18}$ Yet, in a relatively short 
span of time, most of the collegians joined the party and continued to participate in the anti-war campaign. In March 1944, after the Germans had occupied Hungary, the government revoked the people's college's autonomy and the majority of the students either returned to their villages or participated in the underground National Resistance Student Movement led by two collegians, and long standing Communists, Antal Gyenes and András Hegedűs. This group continued to print anti-Nazi propaganda and to cooperate with other left-wing organizations until the Arrow Cross and German army had retreated from the city. ${ }^{19}$

When Budapest was finally "liberated" by the Red Army, the regrouped collegians wasted no time in tailoring their political activities to suit the changed environment. In December 1944, the Györffy collegians occupied a former German language school and, under the guidance of the Communist Party, established the Hungarian Democratic Youth League (MADISZ). According to several sources, the collegians had originally wanted to name the organization the Communist Youth League, but Zoltán Vas, one of the most influential Moscow-trained Communist leaders, convinced the students of the more urgent need to create a mass organization in the spirit of a popular front. ${ }^{20}$ Moreover, because the major political figures of the Peasant Party, such as Imre Kovács and the crypto-Communist Ferenc Erdei, were in their own respective counties, several collegians were also charged with the task of re-structuring the National Peasant Party in Budapest. ${ }^{21}$ In the initial months, they filled the lion's share of the party's leadership positions. $^{22}$

Suffice it to say that the fifty-member people's college, despite being disbanded, emerged from the war a well-disciplined organization with clear leftist, even Communist, credentials, and had amassed an enormous amount of moral capital. It was an ideal ally for the fledgling Hungarian Communist Party. Not only did the leadership and most collegians consider themselves to be Communists - or at least sympathetic to Communism - the fact that the overwhelming majority of members also came from the peasantry afforded the Communist Party inroads into village life, where their appeal was traditionally low. This perhaps explains why, when radical land reform was enacted in the early months of 1945, the Party entrusted the collegians with the distribution of land in more than half the counties in Hungary.

\section{Land Reform}

The agrarian reform of 1945 was an event in the history of the Györffy People's College that bestowed a great deal of pride on the participants. For those peasant students in their early twenties, it meant that they had become the arbiters of a grand-scale land distribution program which their own parents and grandpar- 
ents probably never would have imagined possible. ${ }^{23}$ József Pál, a member of the National Cooperative Council and former collegian, recounted his joy in returning to his village to distribute land. "Next to the Church was a mansion with a gigantic, beautiful park that was not open to the public. The villagers had never before been inside. Well, as ministerial commissioner I ordered it to be opened... and after church on Sunday the park's gates were unlocked and I told them to go inside...that day the park was filled with people, walking in and out to have a look for themselves... and within a week all the land was redistributed."24

But land reform did not always go so smoothly. In a 1989 interview, András Hegedús explained how revolutionary the concept was to many of the peasants and how reluctant they were at first to claim the land. "Farmhands, day laborers, landless peasants. For them taking the land presented several ethical problems, 'it is not his, [they said.] Why is he taking someone else's land?' This problem arose in four or five communities in Zemplén [county]. When it did arise, I was forced to go out and canvass [agitál] support. I had to convince the people to accept the land. Later, when I was land distribution commissioner in Sopron County the same problem cropped up. In the end, most people accepted it. Their hunger for land was stronger than their reserve." ${ }^{25}$ It is not surprising that this experience had a profound effect on the participants and emboldened them to participate more fully in Hungarian political life.

\section{The Birth of NÉKOSZ}

The influence and membership of the people's college organization grew exponentially in the subsequent months. People's college life resumed as a second generation of collegians replaced those veterans who had finished their coursework and received their degrees. In 1945, the veterans established the Society of Collegian Graduates and continued to live a communal life together in the hills of Buda. They also remained active members in people's college life, overseeing its operation and later filling leadership positions within the NÉKOSZ movement.

The actual events surrounding the establishment of NÉKOSZ have yet to be clarified by historians. In 1946, university students founded the Petőfi People's College basing it on the Györffy People's College model. According to a 1947 article published in the NÉKOSZ journal Március Tizenötödike, a minor "internal conflict" broke out in the people's college and the "Györffy collegians were called in for assistance." After the "traitors of the progressive youth" were purged, the two independent people's colleges voted to merge together and form the National Organization of People's Colleges (NÉKOSZ). ${ }^{26}$ A more plausible explanation is that there was a struggle for power between those students who wanted to merge 
into the NÉKOSZ structure and those, like the principal, who did not. In an interview, Maria Pogány, the widowed wife of László Kardos, candidly admitted that the Györffy collegians orchestrated the takeover by sending enough students to the Petoffi People's College to form the majority needed to vote in favor of the merger. ${ }^{27}$

Despite these dubious beginnings, a movement was born which helped shape the political and social transformation of post-war Hungary. Owing to a massive recruitment campaign in the villages and factories, people's colleges mushroomed throughout the country. By 1949, the year of its demise, the number of people's colleges had exceeded 150 with a combined student body of over 8000 collegians.

\section{Life in the People's College}

To visualize the degree to which ideological factors influenced these peasant and, to a lesser extent, worker students in life in the people's college, it is first necessary to describe the unique aspects of the people's college which emerged during the initial years of the movement and took full shape in the postwar period. Like normal dormitories, each university people's college was furnished with an open library, dorm rooms and a dining room. However, the similarities end there.

The internal structure of the people's college served to foster a closely-knit community based loosely on a combination of democratic and Marxist ideals. The smallest unit of organization within the people's college was known as a "cooperative." This was a dorm room, housing between 5 to 20 members, which functioned as a virtual collective. Care packages from the villages were distributed evenly among the members, there was no private property per se, and everyone was given a set of responsibilities, including such tasks as organizing sporting activities, writing articles for one of the two NÉKOSZ journals, or fulfilling a leadership position within the group.

In order to preserve each people's college's autonomy, every semester the members selected their own principal, first secretary, and other officers. ${ }^{28}$ Most often collegians themselves, these leaders were responsible for ensuring that life in the people's college ran smoothly, tasks from the NÉKOSZ central office were fulfilled, and that the community retained certain cohesiveness. To help promote unity and discipline, certain mechanisms became permanent structures of the college. For example, the people's court [népbiróság] was an elected body of collegians authorized to mete out punishment to those members who did not follow the rules of the college. In rare cases, the sentence could even include expulsion, though most often the penalty was less severe.

Another important internal mechanism was the so-called criticism/self-criticism. This was a two to three day exercise whereby each collegian, including the 
members of the leadership, had to undergo a series of cross examinations by their peers and was expected to practice self-criticism. According to several collegians, criticism/self-criticism was first employed during the war when it acquired its religious undertones; many liken the process to a confession in which the students could purge themselves of their sins against the community. ${ }^{29}$ Those collegians who defend criticism/self-criticism contend that the process was most often carried out humanely and that it promoted unity and understanding among the members. It was only in the final year of the movement, they claim, that the practice assumed a bureaucratic, Stalinist quality and was strictly used force members to toe the party line. ${ }^{30}$

Because each people's college was autonomous, a quota or "norm" system was adopted to promote a higher degree of uniformity between the different colleges and a more professional environment. In addition to the school work expected of normal students, collegians were also required to fulfill daily and monthly "norms" that were determined by the NÉKOSZ central administration. A typical day as recounted by one collegian included waking up around 6 o'clock, eating a light breakfast of milk, a latté and some bread. After breakfast, there was an hour of silence during which students worked on their homework in the people's college library. If they finished early, the students were expected to read quietly - usually one of the 30 or so books prescribed by the central leadership. ${ }^{31}$ Then the students attended foreign language class or chorus in the people's college until lunch. After lunch the students headed off to school on foot and were expected to return to the people's college for dinner. Each evening at 8 o'clock, the group gathered to sing folk and "revolutionary" songs. ${ }^{32}$ In addition to this, twice a week there was a guest lecturer (a well-known writer, journalist, politician or scholar) who would visit the people's college and speak on a prearranged topic. ${ }^{33}$ These speeches were always followed by open discussion, sometimes lasting well into the night. ${ }^{34}$ If there was no guest lecturer scheduled, then the students might take part in a meeting of one of the numerous political youth organizations or planned cultural events. On the weekends, students often conducted the required sociological studies on village or factory life or participated in several intramural activities such as sports and folk dancing.

One key element to NÉKOSZ's success was the active recruitment of talented peasants. Collegians were selected on the basis of a complex system of testing. Each summer, the collegians organized "application camps" for peasant students whom they had recruited from villages throughout the country. These applicants lived with the collegians for three days and endured many stressful hours of exams. In addition to writing an autobiography, critiques of theater performances, and several essay questions, students were also asked by a committee of collegians a series of "lightning questions" to test their intellectual acumen and, judging from some of the questions, locate their political loyalties. ${ }^{35}$ According to a 
1947 speech given by Kardos to those collegians responsible for selecting new members, the criteria for acceptance included the following. Socially, "we should admit only proletarians, peasants, and the most progressive from the petit bourgeoisie." Politically, "that is from a class standpoint, it is necessary that the students be 'suitable' and appropriate for all circumstances." And finally, pedagogically, "students must be able to adjust to collective life"; in other words, they must be community oriented.

Parallel to the rigid disciplinarianism of each people's college, there existed a unique democratic spirit not found in the Stalinist organizations that would supersede it. Open political discourse and the expression of a variety of opinions were tolerated, even encouraged, within the walls of the people's college. This does not mean, however, that the views expressed in the people's college spanned the entire political spectrum. They did not. The selection process ensured that applicants who were hand picked by the leadership shared a general worldview. On the other hand, although these students overwhelmingly supported a radical transformation of Hungarian society, their individual brand of radicalism often strayed from that of the Communist Party, and even from that of the NÉKOSZ leadership. In the December $5^{\text {th }}, 1946$ sitting of the Hungarian Communist Party's Youth Secretariat, the NÉKOSZ representative, Gergely Szabó, informed the committee that their biggest problem was that the Communist peasant party instructors recommended by the NÉKOSZ central leadership are not always chosen by the members of each people's college. He also complained of a "renegade" people's college run by a "right-wing National Peasant Party priest" and the fact that that there were not enough "appropriate" teachers to run the lyceums. ${ }^{36}$ Although Marxism was prescribed by the central leadership, the large degree of autonomy within the people's college led to the emergence of highly individualized and sometimes outright contradictory ideologies. It was not uncommon, as one diary entry reveals, for a collegian to attend mass in the morning and then, having returned to the people's college in the afternoon, read a Hungarian Communist classic such as The Four Hundred Year Struggle for Independence..$^{37}$ In fact, there were people's colleges in which the entire student body attended mass on a weekly basis despite their materialist education. ${ }^{38}$

\section{The Golden Years}

The years between 1946 and 1948 marked a golden period in the history of NÉKOSZ. During this time, the movement attained power and political influence far exceeding all other educational movements in Hungary. Initially, even the Smallholders Party, the Communist Party's most formidable opponent, supported the movement's ambitious plans for expansion. This need not be surprising since 
its message was inclusive and appealed to a broad audience. In the true spirit of the popular front, NÉKOSZ was touted as a nonpartisan institution which promised to bestow upon poor peasant and worker students an education that would not only help to bring about an eradication of the inequalities of the Horthy regime, but also assist in the creation of a new democratic Hungary. István Bibó also expressed this need in his 1947 article entitled, "Intellectuals and Professionalism." In order to set high standards of professionalism, he argued, it was necessary "to create the conditions that would give special educational opportunities to talent that has been thus far denied proper schooling. Above all, the largest share of opportunity must be extended to the isolated, impoverished peasantry." ${ }^{39}$ The expansion of education that took place in Hungary during this time contributed further to the rapid rise of the movement. The number of university students in Hungary during the 1946-47 academic year doubled that of the 1937-38 year. ${ }^{40}$ NÉKOSZ was able to select among the brightest from this influx of new students.

Despite the movement's popular front policies and its democratic and diverse ideological makeup, there is enough evidence to suggest that the Communist Party exerted an overwhelming influence on the people's college movement. The Communist party compromised the most influential leaders of the movement. On the one hand, there was a small group of collegians that quickly rose through the ranks of the party nomenclatura. To list just three, András Hegedüs, who would later become the prime minister of Hungary, was then a representative in Parliament and the leader of the Communist Youth League; and László Tőkés and Béla Szalai served as the secretaries of László Rajk and Mátyás Rákosi respectively. These men were sent to party schools and, not surprisingly, most often toed the party line. ${ }^{41}$ Their role in the NÉKOSZ movement was as influential as it was colored by their subordination to the imperatives of the party. There were also leaders of the movement such as László Kardos and his loyal followers, who were members of the Communist Party and also remained directly involved in the dayto-day operations of the NÉKOSZ movement. Like the first group, these members were well informed of party decisions and had direct access to key leaders in the Communist Party hierarchy, especially to the two benefactors of the movement, László Rajk and József Révai. However - as will become evident later in the work - unlike the first group, these men also attempted, with limited success, to preserve the autonomy of the movement.

Although it is difficult to determine to what degree either of these groups can be considered "Stalinist," both ensured that NÉKOSZ would back Communist agendas when deemed necessary and that the education provided in the people's colleges would not only be Marxist but also supportive of the Hungarian Communist Party. ${ }^{42}$ The significance of this dynamic should not be underestimated in judging to what degree ordinary members were Communists. Since most of the 
students did not enter college life with set ideological loyalties, and their knowledge of Marxism-Leninism was most likely minimal at best, it was up to the leadership to shape their education and provide the proper direction. According to Antal Gyenes, the president of NÉKOSZ in 1946, a Communist education was central from the start despite pretensions that it was a nonpartisan organization. The claim that NÉKOSZ was a popular front organization "is simply not true," he argues. "We wanted to raise Communists, Marxists or Marxist sympathizers, and that is the truth, whether it was right or wrong...In the beginning we enjoyed good relations with all parties, even with the president. ${ }^{43}$ They even attended our celebrations. Nevertheless, the education was a Marxist education." 44

Evidence that NÉKOSZ was a Communist organization can be also gleaned from the reactions of the Smallholders and Social Democrat parties. In October 1946, the Smallholders Party decided to establish people's colleges of their own, calling it the Hungarian College Alliance, or MAKE. In his speech, József Varga, the secretary of MAKE, rationalized the decision stating that despite the many similarities with NÉKOSZ, "we are not and will not be Marxists." ${ }^{45}$ Seven months later, the Social Democrats followed suit and formed the National Organization of Worker People's Colleges (DOKOSZ). The reasons for their decision to create an alternate network of people's colleges were expressed in the letter written by the Social Democratic party's Secretariat of the Intelligentsia [értelmiségi titkárság] to the Party's First Secretariat. It stated that

NÉKOSZ (which is for all purposes entirely under the Hungarian Communist Party's control) maintains more than 30 people's colleges in Budapest ... 90 percent of NÉKOSZ leadership is made up of members of the Hungarian Communist Party, the rest are of the National Peasant Party. There are no Social Democrats. There is a total of around 20-30 Social Democratic members who suffer for their party membership. In the case of NÉKOSZ we should not expect compromise on party lines, but rather a battle. ${ }^{46}$

Both MAKE and DOKOSZ were unable to secure the financial backing to effectively challenge NÉKOSZ's monopoly on the people's college movement. ${ }^{47}$ Poorly funded and lacking proper organization, these people's colleges paled in comparison to the well-run people's colleges of NÉKOSZ. After a series of conflicts (on one occasion even resulting in blows) between the NÉKOSZ and DOKOSZ students, the Communist Party forced both organizations to merge with NÉKOSZ in $1948 .{ }^{48}$

Ostensibly a nonpartisan organization, from the outset the collegians participated in national politics and exerted a strong influence on the various youth organizations throughout the country. ${ }^{49}$ This they were able to do with striking efficiency. Owing to their discipline and organizational skills, many collegians played 
leading roles in such mass youth organizations as the League of Hungarian University and College Unions (MEFESZ) and such Communist organizations as the Hungarian Democratic Youth League (MADISZ). The participation of collegians in these organizations created the conditions by which the Communist Party could better direct the course of debate and even shape the actions of each group. Although these organizations may not have been under the complete control of the party - nor, for that matter, were the actions of each collegian - the influence of the Communist Party was strongly felt as a result of NÉKOSZ participation, providing a useful "popular front" ally that was publicly non-affiliated with the Communist Party, but privately supportive of its aims.

Again it should be emphasized that initially it was not in the interest of the party to draw a clear line between Communists and non-Communists - either in these organizations or in the NÉKOSZ movement. ${ }^{50}$ Even MADISZ was touted as a popular front organization and included non-Communists in the leadership. This explains why the Communist Party tolerated a wide variety of ideological freedom within NÉKOSZ. Politically, popular front politics better served the interests of the Communist Party in the first few years because it bought them needed time to strengthen their forces and gain democratic credibility with the population. Moreover, international circumstances would not allow open confrontation between the two antagonistic parties in Hungary. Yet, as the Hungarian Communist Party began to consolidate its power, Communist leaders and many NÉKOSZ members gradually began to adhere less and less to popular front tactics. By 1948, it became clear to most everyone that the popular front coalition was merely a facade. Even NÉKOSZ no longer maintained its original nonpartisan pretense.

One method by which NÉKOSZ supported the party was through its press. The two NÉKOSZ journals, Kollégista and Március Tizenötödike, often served to propagate Communist ideology and policies. For instance, in June 1948, NÉKOSZ published an open letter in one journal supporting the nationalization of schools. On the same page, the editor attacked the policies of those Catholic circles that afforded education not to "talented worker and peasant children, but to the privileged rich." ${ }^{51}$ By 1948, articles were published on a variety of Soviet themes such as the educational techniques of Makarenko, the writings of Pavlenko, and paeans to Mátyás Rákosi, a standard during the subsequent period known for its "cult of personality." ${ }^{2}$

With varying success, many collegians also took part in several "Communist" projects. In his diary, Sándor Pető explains how he and other Györffy collegians were sent to villages to garner support for cooperatives in the summer of 1946 . Although this was an exceptional case, his writings offer insight into the psychological relationship that some collegians had with Communism and provides an example of the challenges faced by collegians who were branded as "janissaries" of the Communist Party by the non-Communist press. ${ }^{53}$ 
25 July: [At the office of Bolhó director of land claims, Ferenc Lukács] In his room on the wall was a giant picture of Horthy... Why leave it on the wall? What does that mean? I think that it only means that sooner or later he will express the views of Horthy's party, which are not the most democratic. Because of religion (theoretically because of that, but in truth because of his feudal way of thinking) the Communists consider his right to exist incompatible [with a Communist society].$^{54} \mathrm{He}$ also declares, like so many other nitwits, that the peasant party is the countryside subsidiary of the Communist Party. He complains that they want to get rid of him because he has always served the interests of the people, and is serving the people's interest now as well.

28 July: I argued so much. I have butted heads with many dim-witted, stubborn, feudal-type characters. You can hardly get them to understand the truth...

31 July: The village judge is the most closed-minded peasant, and is perhaps the shadiest politically as well... When I told him about my mission he stated: We don't accept anything that is from the radical left...We don't need any kind of cooperative here, the Peasant League [run by the Smallholders Party] was established and we will be farming with the Danish model.

3 August: The director, Lukács, is now speaking with Jadi, the obstinate Peasant League member from Bolhó who is the most opposed to a fm. cooperative. He already promised to give me a beating and told those people we are negotiating with that I am Jewish, etc. They have already accused me of bribing the director with a new job. ${ }^{55}$ The people are very distrusting, they still do not want to believe what they hear with their own ears and see with their own eyes.

According to Petó, József Lukács of the Smallholders Party gave a speech the next day in which he told the residents of Bolhó and other surrounding villages, not to join the cooperative. Petô was forced to return to the people's college empty handed. ${ }^{56}$

Mobilizing the masses became one of the most effective means of the Hungarian Communist Party to control the political discourse and force the adherence of their demands. In the latter years, the people's colleges became a reliable source of manpower for the Communist Party. On a number of key occasions, the collegians marched the streets in support of the party's agenda. Ádám Szirtes, a former collegian, recalled in 1970 that,

Before election we took to the streets, sang, danced and lectured [szavaltunk]. But not just on the streets, I remember on the HÉV ${ }^{57}$ as well... and we lectured to the people returning home from work who 
were reading the newspapers, playing cards or looking for something to occupy themselves with...we would just jump in front of some young person and start to sermonize. What a strange situation it was...we went home with such feeling of victory if we had managed to win the attention of one or two people...Before the elections, we would jump into a huge truck, ten or fifteen of us would hold on as we drove to the mining camps, Salgótartján, Dorog, and to areas surrounding Miskolc. [There] we gave lectures and held cultural programs; two to three hours of announcements, singing and sermons. ${ }^{58}$

The disciplined and politicized nature of life in the people's college, the inculcation of Marxism-Leninism and Communist propaganda, combined with the turbulent period, created the perfect conditions for a radical youth organization that often, though not always, played into the hands of the Communist Party. Although it was neither necessary nor really desirable for the party to integrate the entire movement into the party nomenclatura, these students, along with other segments of society, proved more than willing to support the Hungarian Communist Party when asked to do so. The reason for this can partly be explained by the guiding influence of the Communist leaders in the movement and because the Communist Party offered them an ideology of hope, promising to eradicate the inequalities of the Horthy regime and create a society that would cater to the peasantry and to the working class. In the same vein, the party convinced the students that they would become the future leaders of the nation, a belief strengthened by the apparent omnipotence of the Hungarian Communist Party in dictating the course of events in the country. It is not surprising, then, that as the Communists gained the upper hand in Hungary, Marxism-Leninism became increasingly more central to collegian life.

\section{The Final Year}

On 15 March 1948, unaware of the dramatic events in store for them, five thousand collegians marched in procession singing hymns to commemorate the centennial celebration of the 1848 revolution. It was a spectacular day for László Kardos as well. Not only had he marshaled an impressive army of collegians for the celebration, but he also received the nation's most prestigious honor, the Kossuth Award, for his "pedagogical and organizational" work in the service of democracy. His future and the future of NÉKOSZ seemed promising. But "underneath the unsuspecting celebratory and auspicious appearance," recalled Kardos, "the historical powers were preparing something entirely different." ${ }^{59}$ Four days later, in a meeting of the HCP Central Leadership Organizing Committee, attended by Mihály Farkas, ${ }^{60}$ József Révai, László Kardos, Antal Gyenes and others, the Com- 
munist Party ordered the NÉKOSZ leadership to sit down with the Communist Youth Secretariat and work out the movement's "ideological errors." 61 The die had been cast.

Within the next several months, the HCP leveled a series of criticisms against the NÉKOSZ movement and even contemplated its incorporation into the state school structure. Initially, everything was kept behind closed doors. The party accused the movement of embodying a harmful chauvinistic and independent spirit tainted with avant-gardism and narodnyik romanticism that threatened the relationship between the students and the Communist Party. As a consequence, the Györffy István People's College, the prototype of the people's college, was closed down indefinitely, the leadership intensified the political activism of the movement and restructured the summer application camps to emphasize the tenets of Marxism-Leninism. ${ }^{62}$ But reform proved too little too late. Come middle of summer, criticisms by several factions within the Communist leadership surfaced in the press. NÉKOSZ was thrown on the defensive yet again.

"What was virtue yesterday, is backwardness today, and will be tomorrow negligence, indeed, a crime," wrote the Marxist philosopher György Lukács in a June article in which he criticized NÉKOSZ's "lack of professional training" and "sectarianism." "A new type of person is needed," he argued, one that is "a convinced democrat, socialist and educated professional, who is able to effectively work in public life." ${ }^{63}$ One month later, the newly formed Györffy István People’s College Communist Committee issued a statement that blamed the movement's sectarianism, "the replacement of democratic centralism with dictatorship" and other "ideological errors" on László Kardos and accused him of creating an "un-partylike atmosphere" in the movement. ${ }^{64}$

To make matters worse, just one week after László Rajk, NÉKOSZ's staunchest supporter among the Communist elite, was replaced as Minister of Interior, László Kardos was called in front of the HCP Central Control Committee for alleged crimes of sexual misconduct and promptly forced to resign from his post. ${ }^{65}$ Included in the charges to discredit him was the claim that, "as a married man he conducted relationships with more than one woman at the same time. He accused those who were not willing to fulfill his desires of having petty bourgeois inhibitions unworthy of a Marxist." ${ }_{66}$

No sooner had the leadership been replaced when József Révai, who up to this point had always staunchly defended the people's college movement, gave a scathing invective before a NÉKOSZ Communist committee in which he accused the movement of peasant romanticism, sectarian isolationism, and neglecting their professional training which, he intimated, were remnants of their contact with right-wing ideologies under the Horthy regime. Adding a premonition, he stated, "We must ask the question: does NÉKOSZ speak forever? No, it doesn't, and no collegian should regret this. It is not the form but the essence that we are in love 
with. It is not so important that we win over the Hungarian youth for democracy and Communism with NÉKOSZ, but that we win." ${ }^{67}$

At this point, those aspects of the people's college that had once served to strengthen the unity of the community began to tear at the very fabric of life in the people's college. NÉKOSZ became more bureaucratic and centralized; the selection of new students was restricted to party cadres from the proletarian class; the quota system intensified as participation in political youth organizations became compulsory; more power was placed in the hands of each people's college's principal and first secretary; and a simplified Marxism-Leninism infiltrated all aspects of educational life. Before long the internal cohesion of the people's college began to unravel. Without any restraint, criticism/self-criticism took the form of a Communist Inquisition. Members accused one another of harboring reactionary beliefs, expulsions occurred on a daily basis, and the community was split apart. This state of disarray is depicted in the diary entry of one student. He writes,

6 February: Unfortunately, we had to expel ten members from the people's college today, among them Gyenes, Ruszkai and Sándor Barna too, all of who were my good friends. I did everything I could to get them to stay, but [my efforts were] in vain. I feel sorry for them because we were such good friends, but I just wasn't able to reach a positive outcome on their behalf. ${ }^{68}$

Newly appointed NÉKOSZ leaders, such as Ferenc Pataki, accelerated these trends by calling on principals to intensify "the class struggle" by "rooting out" harmful elements in the people's college and implementing the pedagogical methods of Soviets like Makarenko." ${ }^{96}$ By the end of the 1948-49 academic year, it was clear to everyone that NÉKOSZ, as they knew it, was through. In fact, by the time NÉKOSZ was implicated in the László Rajk show trial of June 1949, it was already in the late stages of nationalization, ${ }^{70}$ having suffered the same fate that had befallen other semi-autonomous organizations. In the summer of 1949, the people's colleges were officially handed over to the state - many to be duly transformed into dormitories for the szakérettségis program - and the collegians were dispersed and sent to various schools within the new state educational system. ${ }^{71}$

With the opposition out of sight, it was only a matter of time before the party would turn on itself in the interest of eradicating all autonomous or even semiautonomous elements. To quote Arendt, "Totalitarian movements are mass organizations of atomized, isolated individuals. Compared with all other parties and movements, their most conspicuous external characteristic is their demand for total, unrestricted, unconditional, and unalterable loyalty of the individual member." 72 NÉKOSZ was the logical target of the purges since it was easier for the Party to start from scratch and establish a new educational system than to rely 
on the reforms of a movement with strong democratic and ideologically questionable traditions, even when the movement had been so useful to the party during the transitional period. NÉKOSZ had served its purpose and had become expendable.

\section{Revolution Revisited}

In the course of a few years, the collegians went from being the "janissaries of the Communist Party" to the "janissaries of Tito," and the movement passed away, an institutional pariah in a society it had helped to create. Under the reign of Rákosi, there was little attempt to change this status and virtually no mention of NÉKOSZ in the press. But following the death of Stalin and the elevation of Imre Nagy to the Hungarian prime ministership, László Kardos and István Márkus, another former collegian, authored a memorandum in which they argued, among other things, that the liquidation of NÉKOSZ had caused harm to the peasant youth movement, and that people's colleges should be re-established if only to create a "civic" intelligentsia, one that was sorely needed in the country. ${ }^{73}$ Initially, the memo sparked fierce opposition, especially from the Democratic Youth League, and the plan was shelved under the threat of prosecution. However, at the behest of the Petófi Circle, ${ }^{74}$ led by the former collegian, Gábor Tánczos, the plan surfaced during the dramatic months preceding the 1956 revolution. Although the ten-year anniversary celebration of the movement was cancelled by the Party due to certain "anomalies" within the Petöfi Circle, the tide had turned in NÉKOSZ's favor. The leadership of the Democratic Youth League adopted a more conciliatory approach in tune with the political climate. Ervin Hollós, the league's secretary, publicly admitted that NÉKOSZ had been wrongly accused of conspiratorial designs against the state. ${ }^{75}$ Moreover, in a September session of the Political Committee, the leadership even approved a plan to re-establish people's colleges throughout the country. ${ }^{76}$

But in yet another ironic twist of fate, these plans were dashed by the revolutionary events. For a second time, the collegians found themselves on two opposing sides of a conflict. It was the Petőfi Circle, led by Gábor Tánczos, that spurred the revolution in the first place, and András Hegedüs, as prime minister of Hungary, who invited the Soviet troops to squelch it. ${ }^{77}$ Once the revolution was put down, the "counter-revolutionaries" were tried and imprisoned. Among those imprisoned for the participation in the uprising were Kardos, Tánczos, and other collegians. $^{78}$ Tánczos received ten years imprisonment of which he served four and Kardos received a life sentence of which he served six. 


\section{The Movement Evaluated}

If we look at the history of NÉKOSZ strictly from a political perspective, it is evident that the movement played into the hands of the Communist Party. Not only did NÉKOSZ contribute to the popularization of Communism, but more significantly, it also provided the Hungarian Communist Party with an ample and reliable source of cadres necessary to carry out Rákosi's ambitious Stalinist policies. Judging from this point of view, it appears that NÉKOSZ's trajectory followed a familiar path: genuine coalition, sham coalition, consolidation of Communist power followed by internal purges. The participants, it would seem, were led effortlessly down the path to the denouement.

Herein lies one flaw of traditional history. Although the reader is presented with a coherent narrative that recounts the chronology of noteworthy events and is left with a general understanding of the political significance of the movement, something is missing from this account. This history of the movement lacks a convincing explanation as to why these students allowed themselves to become the tools of the Communist Party, and it fails to present the everyday experiences of "ordinary" collegians. What is missing from this history are complex characters. For the remainder of the work, I will complicate my interpretation of NÉKOSZ by presenting the movement from the perspective of the participants as they look back on their experiences.

\section{Section II Memory of a Movement}

This second half of this work will be divided into two sections. The first examines the "authoritative memory" of the movement as depicted during the Kádár period. By "authoritative" memory, I mean memory that both falls outside of the private sphere and is presented - and often received - as a definitive interpretation of how events actually transpired to such an extent that the "authoritative" memory often shapes "individual" memory when people attempt to recall their own experiences. The analysis in this section will include a brief outline of the five-volume

collection of documents edited by a number of former NÉKOSZ leaders as well as the controversial film directed by the former collegian Miklós Jancsó.

The second section explores how "individual" memories can not only offer insight into the motivations behind the actions of these students but also complicate some of the assumptions of the first half of the work. In this section, I use excerpts from a collection of personal interviews conducted in November, 1999. Though the pool of informants is admittedly small (only eight in all) and not as varied as would be ideal (the informants were provided by three sources and they 
represent three separate groups with minimal inter-group contact), the purpose of this section is not to provide the reader with a broad sociological survey but rather a collection of individual interpretations that might shed light on different aspects of the movement's history. It is intended that both sections will give a more colorful and complex interpretation of NÉKOSZ, and leave us with a better understanding of how memory and oral history intertwine.

\section{Divided Memory}

In 1969, György Aczél, ${ }^{79}$ the Central Committee Secretary of Cultural Affairs, Kardos, and several former NÉKOSZ members, sat together in a pub, drinking and singing old revolutionary songs. When it appeared that Aczél was in good spirits, Kardos asked him,

"Hey Gyuri, do you think that NÉKOSZ was progressive?"

"Naturally," he answered.

"The progressive line of the worker movement too?" asked Kardos. "Yes."

"And don't you think that now would be the time to clear up exactly what was NÉKOSZ, the criticism of the party, and everything else?"

"Of course." stated Aczél.

"Well then, help us." 80

Not long afterward, György Aczél gave Kardos and others official permission to gather material on NÉKOSZ and eventually publish their findings ${ }^{81}$ In the late 1970s, four volumes of NÉKOSZ documents and an ambitious survey appeared in selected bookstores in Budapest. The publication of these works served as a vindication of the charges leveled against the movement during the Rákosi period; NÉKOSZ once again attained its rightful place among the pantheon of "progressive worker movements." More importantly, to the former collegians these works comprised a memento of their movement, forming a veritable "imagined" community of times past. In the words of one editor, these publications constitute "a confession of a generation," a confession all the more compelling in light of its "scientific" credentials - over 3000 pages of primary documents, detailed questionnaires and statistical charts that pooled over 900 out of the almost twelve thousand participants of NÉKOSZ - and its appearance of objectivity and tolerance for a multiplicity of views. ${ }^{82}$ All essential aspects of the movement were dealt with separately and placed in their logical order, e.g., the ten-year history of the original people's college, the movement's internal structure, its "golden age" followed by the "professionalization" period and the final year when NÉKOSZ was merged into the state educational system. Included in this impressive collection of information were interviews, diary entrees and even a debate on the infa- 
mous film about NÉKOSZ, Bright Winds [Fényes Szelek], directed by the highly acclaimed filmmaker and former collegian, Miklós Jancsó.

The format was simple. The editors introduced each theme with a short summary, a suggested interpretation if you will. Following each summary, they offered a compilation of carefully arranged primary documents, usually abbreviated and set in chronological order. For the most part, the documents corroborated the preceding summary, but in several sub-sections there were contradictions as well. The reader was left with a choice, either to accept the interpretations offered by the editors, or to create his or her own interpretation. The fact that these five publications were the fruits of a collective project of former collegians, including the most influential leaders of the movement, lent greater credibility to its claims. It was after all, an internal affair. Over 20 former collegians are included as editors and assistants, including Kardos, Gyenes, Tánczos, S. Györffy, and even Ferenc Pataki.

It is not the purpose of this work to give a detailed critique of this enormous work; it is enough to present some of its more prominent characteristics and arguments. It must first be stated that the work represents the efforts of collegians that sought to portray NÉKOSZ in a positive light. It was also the product of the Kádár period. The authors were faced with the difficult task of presenting a movement that was on the one hand, progressive and Communist in the "popular front spirit" and, at the same time, unaffected by the Stalinist predilection towards violence and terror. Understandably, the authors omit some information that would have blackened the movement's image. For example, there is no mention of what really happened with the Petöfi People's College when it voted to merge with the Györffy People's College, nor do they give an accurate account of their role in the liquidation of the DOKOSZ and MAKE people's college movements. It is also no surprise that there is no mention of the events of 1956, or of attempts to re-establish the people's college movement. And yet, despite these lacunae, the breadth of the work is enormous. The authors made a point of including a variety of interpretations that at times present a rather conflicting picture of the movement. This gives the work a pretense of objectivity and complexity that is absent in many historical works written in the Communist period.

There are several motifs that remain stable throughout. Most importantly, the authors repeatedly refer to the NÉKOSZ ethos, that is, the movement's emphasis on democracy, diversity and a commitment to each people's college and the community-at-large. Also essential to their interpretation is the "Györffy Legend," i.e., the heroic struggle against Fascism, the claim that NÉKOSZ was one of the first victims of the Stalinist purges, and the recurring reminder that these participants sincerely believed in the NÉKOSZ anthem; that they were the "bright winds" that would "overturn the entire world." 
The influence that these five works have on the memory of many of these former collegians should not be underestimated. As will be evident later in this work, not only did virtually all of the persons with whom I spoke refer to the fivevolume work, but the ideas presented seemed to still resonate in their minds, especially among those participants who did not play a leadership role in the movement. During my first week in Hungary I attended a meeting of the Friends of the Bright Winds [Fényes Szellök Baráti Kör], a group of ex-NÉKOSZ students - all in their seventies and eighties - who are actively campaigning to reintroduce a NÉKOSZ-like movement in Hungary. ${ }^{83}$ After a speech on contemporary Hungarian politics, delivered by a Hungarian Socialist politician and former people's college principal, the floor was opened for debate. More than twenty years after the five volumes of documents were published, an old man stood up, shaking in anger, and criticized "that NÉKOSZ work" which "did not even mention my name" despite the fact that he had participated in the 1939 meeting in which the idea for such a people's college was first purposed.$^{84} \mathrm{He}$ felt that he had been unjustly barred from history.

\section{Bright Winds}

The only counter-memory of NÉKOSZ to emerge in the Hungarian socialist press is the controversial 1969 film entitled Bright Winds. The film offered another interpretation of the movement and reached a much larger audience than did the five-volume work that was published later.

Rather than recount the movement's entire history, Miklós Jáncsó decided to depict the movement metaphorically in its transformation from democracy to dictatorship. The movie opens with a group of collegians who break into a Catholic school and begin to preach to the students. Because of the volatile political situation of the period, the priests are powerless to stop them. They are forced to watch from a distance as a group of enthusiastic collegians round up their reluctant students and preach to them about democracy and freedom. In the first half of the film, there is little dialogue, only the constant barrage of revolutionary songs. There is a surreal sense of optimism and unity among the NÉKOSZ members. As the film progresses, however, unity turns to chaos. The people's college leaders, all students, begin to bicker about whether or not to use force against the unresponsive Catholic students or try to convince them with words of the error of their ways. One police officer, and former collegian, even wants to arrest some of the recalcitrant students. The tension and conflict within the group intensifies and one leader resigns on the spot and leaves the premises. Meanwhile, other collegians dressed in priestly garb run through the halls singing and laughing. At that point, 
the NÉKOSZ central leadership enters, and, after a quick survey of the situation, they decide that the college leaders should be expelled. A meeting is held without the presence of the accused and the students are told to vote for their expulsion. Just when the accused are read their verdict, the NÉKOSZ leadership reconsiders and allows them to remain in the people's college. What began as a symbol of democracy and freedom ends in the arbitrary rule of the NÉKOSZ leadership.

The film also influenced the way in which the movement is remembered. In the course of my interviews, the topic of the film always came up. Interpretations varied greatly. While some thought that the film was not at all about NÉKOSZ, but rather about the Stalinist period in general, others gave more complex answers. For example,

\begin{abstract}
Inf. \#7: I didn't want to see it. But then it was on TV and so I saw it. I thought it was very childish and simply not true. But I thought about it and about half an hour later it hit me. It came to me that when they told us it was democracy, it wasn't exactly. I don't know if you are familiar with the film, but there was one scene where the students were singing, dancing, and playing all types of games in the open air, and meanwhile, the leadership determined how things would be. It occurred to me about an hour later, with my husband, that it was true. Really. It was true because many times when we thought that "now, we are deciding," and "it is truly democracy," most likely it was the leadership that decided. It was just masked. So it was a terrible feeling then. I don't know if that is what Jancsó had in mind when he made the film, but for me, years after [NÉKOSZ], with this film, it occurred to me that there wasn't true democracy, and that perhaps, there doesn't even exist the real democracy that we imagined..$^{85}$
\end{abstract}

The fact that this film was able to influence this woman and the publications were able to anger the man who had been left out indicates that these histories were successful on at least one level. They offered the participants a backdrop against which to remember the movement and created a guideline by which to judge all subsequent statements about the movement.

Nevertheless, these works cannot monopolize discourse but only present their versions for further interpretation. Like all "authoritative" memories, they are transformed in the process of coming into contact with personal "lived" memory. These memories always fall outside the authoritative discursive framework, as there is always more than one dynamic at play, e.g., the unique life experience of the individual, the present political situation, counter-memories, and contact with other individuals and their interpretations. More importantly, memory is not repetitive and stable, but highly inventive. Memory is constantly re-constructed to adjust to new situations. 
Thus, in order to understand the complexity of these events and how meaning of these events is constructed, historians must turn to the individual. Flawed as individual memory may be, it is here where the collective and the personal collide; where meaning is constructed. For a number of obvious and not so obvious reasons, the task of recalling fifty-year old events was not easy for the informants. Coming into the interviews, I expected to hear a good dose of unreflective references to the above-mentioned books, especially since three of the eight informants contributed directly to their creation. As was later confirmed, all of them, with the possible exception of one, owned copies of the books and were familiar with their contents. It turned out, however, that although there was the occasional reference to the works like "It's in the book" and "I don't know, the book can tell you," the references were mostly indirect. One got a feeling that the majority of the informants still believed in a NÉKOSZ ethos, a common idea that somehow, despite all the "mistakes," the movement was a constituent part to their lives and distinctly positive. In fact, the positive aspects of the movement were often emphasized and there was a reluctance to discuss anything negative. Not surprising, the subjects were unable to look at the history of the movement with emotive detachment.

\section{Without Embellishment}

In the introduction to his autobiography, András Hegedús, former prime minister of Hungary and collegian, commented on the biographical genre and his struggle to remember the past, the past that is often better forgotten:

To find the proper form of expression creates countless problems. How do I avoid introducing myself as I would like to see myself at the time of writing? This type of endeavor falsifies not only the history of our lives, but also our formed picture of histories of the outside world. Danger of this remains even if we determine to be extremely earnest and objective. So, I should introduce both the living and thinking me of today, as well as the person who searches his past and looks for explanations of his past actions, and at the same time, in regards to the motives of these past actions, is still unsure of so many things. In such cases, I have had to hand the leading role from the distortions of subjective memory over to "refined-filtered" facts, thereby giving the reader the possibility to decide for him. Moreover, I ask from the reader that he accept my statements with the proper skepticism, even when objective data are being discussed. No matter how hard I try, I cannot free myself from the great pitfalls of biographical writing. While attempting to give a true picture of my past and everything that happened around me, I am forced to rely, in the 
first place, on my memory. Memory, however, selects mercilessly and those facts that do not fit into the picture often fall out of view, while others become objects of rectification to such an extent that in the end the truth becomes lies ... often biographers do not know either themselves or the time in which they lived. Often, they simply paint a picture of the world that pleases them, and what they think will please the reader. ${ }^{86}$

In the course of my interviews not only did I encounter these "pitfalls" but, for various reasons both obvious and not so obvious, many of the participants also refused to openly discuss certain sensitive aspects of the movement.

\section{Pitfall I}

\section{History as Mission}

The first woman I met came from a poor displaced family that was forced to leave their home in Slovakia after the war. After NÉKOSZ was liquidated she finished her studies and went on to become a newspaper writer and high school teacher. In the beginning of the interview, she stated with pride that she had read the entire corpus of NÉKOSZ documents and even helped type the finished draft.

She was excessively optimistic about NÉKOSZ and had nothing but good things to say about her life in the people's college. In fact, much of what she said reflected the views presented in the five-volume NÉKOSZ narrative, with the sole exception that she tended to downplay the role of Communist ideology in the movement. When I asked her about the selection process she stated,

Inf. \#1: They administered the selection process very intelligently and humanely. They looked at how much concrete knowledge was in [an applicant's] head. But more importantly, whether one had an imagination. So was there enough intelligence? Could they learn, and would they be able to learn? They also looked at a person's worldview, but it was never a criterion, no way, though it is possible that you might find the contrary in the speeches against it, ${ }^{87}$ in no way was it a criterion that one had to be a Communist. ${ }^{88}$

Later, I asked if there were conflicts between the different backgrounds and again her answer was apologetic.

Inf. \#1: Tight friendships formed. But not in any way according to social status. I also had more intimate friends, but I got along with everyone. NÉKOSZ, from this standpoint, was a miracle, that such an inter-dependence was born is difficult to describe. It happened once, later in my life when I was a newspaper writer, that I met with 
a NÉKOSZ student who I did not know ... within ten sentences it was obvious that he was also [a member of] NÉKOSZ. We both figured it out. It is not really a mystery, but just difficult to explain.

One cannot help but note the reference to the indescribable common ethos of collegians and her emphasis that class distinctions were not important within the people's college, despite the fact that the criterion was decidedly class-based.

One good example of how "memory mercifully selects" was our discussion of the last year of the movement's history. Our conversation went like this.

Interviewer: The expulsions started in 1949 ?

Inf. \#1: No, no. In 1949 it was not even worthwhile [expelling students]. Everything was mixed up. By 1949 it was not even a true people's college. No, there were expulsions earlier. I do not know, I do not know. I couldn't tell you names ...

Interviewer: I have read quite a lot of diaries' entrees about it. How on so and so day ten students were expelled.

Inf. \#1: You are right. Of course! 1949 is when the political expulsions began, but by then it was not NÉKOSZ. No it wasn't. [pause] They also expelled me! It just occurred to me, for what-do-ya-call-it, immoral behavior. (chuckle)

But when I was just about ready to end the interview, I discovered why, perhaps, she had painted such a rosy picture of the movement.

Inf. \#1: From the very beginning, when I had heard that someone from the other side of the ocean was researching this, I became almost feverish. The same enthusiasm, curiosity, and how should I say it, same kind of excitement filled me, because the beautiful dream, which for us was not fulfilled, that the beautiful dream could live further, even if only in a critical study, that someone can refer to it after such a long time, so that once again the flame is rekindled, not for the sake of praise, nostalgia, or old memories, but because I know how much of an influence and help it was for me and many others, and I know that in this poverty stricken world many talented children need this assistance, because they should get it.

There was a similar discussion with Informant \#4, the widowed wife of László Kardos. She admitted to me that she had spent years trying to interest UNESCO in the NÉKOSZ model, and would have succeeded had not the movement been labeled Communist.

Inf. \#4: If someone with the same capabilities of my husband could create a movement using the pedagogic methods [of NÉKOSZ] ... If they could in some way bring out the minorities [pause] because with us, after 1945, those who were accepted into the people's col- 


\begin{abstract}
lege were in the country's minority, they were poor in a rich country. If they could take these minorities, I don't know what the blacks or gypsies are like, I can just guess, but if we could make an organic intelligentsia it would free them, those from the ghetto. This is extremely important and they don't understand it here either, that soon the population of the gypsies will be ten percent in the country. They need their own intelligentsia. This idea, this is the essence, I think. ${ }^{89}$
\end{abstract}

From a historian's perspective, motives like these make it difficult to glean the "facts" of NÉKOSZ - it is impossible to get an objective perspective when personal motivations are so much at play. But to these women, these motivations belong to the history of the movement. History is worked out in the present through the attempt to achieve "dreams" left unfulfilled. These statements say something about how historical meaning manifests itself in the present. It is as if the establishment of a new NÉKOSZ would make their personal experiences historically significant.

\title{
Pitfall II Identity as History
}

One informant, who lived in a poor apartment in Budapest, was unable to separate her time in NÉKOSZ from those past and future events that had also shaped her life. Being an orphan, she was accepted into one of the people's colleges when it was in the process of nationalizing. However, after being a collegian for one year she was permitted to continue her studies in the same people's college as a szakérettségis student. ${ }^{90}$ When we sat down, she immediately started talking. Without stopping, she spoke for the first half hour about all sorts of events not related to NÉKOSZ. Somewhere in the middle of her remembering she said,

Inf. \#7: So when the questionnaire came, I answered it, and at that time as well my feeling was such [pause] so very [pause] so probably I didn't answer it as they would have liked, because then my feeling was such that the whole thing should never have been. ${ }^{91}$ Because ah, I don't remember what year it was, but I am sure that it was not a very democratic period when the NÉKOSZ researcher called. And now it is my opinion that it didn't matter what period it was, it had to be written because a lot would be lost. You know, many have died since then and everything, so there was the chance to really gather [information]. It was very important, but then my feeling was that for me, NÉKOSZ actually caused harm. Because it raised in me a kind of democracy that, well, later did harm. (chuckle) Perhaps, a small reason was that my life did not turn out how I planned because I 
wasn't totally happy and with real bitterness I answered the questions, the NÉKOSZ questions. Not because, you know, I have many friends from the people's college and everything, but nevertheless, it was my feeling that that was the year when, well, something glimmered before us, which possibly arose from society and then nothing came of it, just like in 1956 where something glimmered, and then also disappeared, so that a person felt that there was nothing of it, everything disappeared without any usefulness at all. ${ }^{92}$

When I asked her how she got into the people's college she gave me more information than I could handle. She began, "our family background was not a common one." Her father was an orthodox Jew who was "proud that under the Trianon proviso, he was granted Hungarian citizenship because his family had already been in Hungary [before the war]." Because he divorced his first wife and married her mother, who was a Székely Christian from Transylvania, his family broke off all relations with him. In 1941, he first volunteered to fight on the front lines as a sergeant.

Inf. \#7: Then, when I was four, my mother died. So we children remained. I was the middle child. Then they took my father and we remained alone ... it did not get better later either. My big brother had to hide, and we ... we had to move into the ghetto. So we were attacked by the Christians. But we were lucky because we were able to visit our father. Even when he was stationed in the countryside we got to see him once. In that respect, we were in a lucky position. However, after the war we did not hear anything about him. He lost his life, they probably got him in the countryside. So this does not really belong here, but since you asked.

Later, she described the big celebration of March $15^{\text {th }}$,

Inf. \#7: We were in the theater, and I remembered, as if it was at that point when Révai gave the critical speech on NÉKOSZ. When it meant so much for us to celebrate March 15 th. It was a wonderful feeling that at this time we were young and we "would overturn the world." That it would overturn! And then after - I also wrote this - I met with someone and it turns out that it was Péter Veres who spoke at the theater, and Révai spoke on some other day, somewhere, and made all those charges. But for me it all flows together. Afterwards, there was a huge street ball in the square, where all of the collegians stood. Everyone was there and everyone danced with everyone else. It was an amazing feeling, I don't remember what kind of music was playing, but everyone was in a good mood ... it was a sort of ... I don't even remember. So, perhaps there was a similar feeling of community in 1956. That there were so many young people together. On 
the other hand, I could not experience this, because in 1956 I was not one of the people who lined up [in the streets]. My boy was only a few months old. But my husband was there and I heard everything about it.

During the course of the interview it became obvious that the historical facts did not matter to her as much as the meaning that she attributes to these historical events in the formation of her own identity. No matter how many times I tried to get her to talk about NÉKOSZ she always found a way to intertwine her years there with the rest of her life.

For example when I asked her whether or not she believed in the charges leveled against Rajk and NÉKOSZ, she answered,

Inf. \#7: No. I never believed it. Nor did my husband. I think that many others did not believe it either. Especially [the charges] against NÉKOSZ, nor [those about Rajk] because if someone helped NÉKOSZ it was László Rajk. Well, the Study in Russia camp, which I wrote about, was entirely in the shadow of these charges. We just didn't realize it then. Here they were looking for and chasing the petit bourgeoisie. After the change I also became a member of the petit bourgeoisie. And that is why I was forced to leave, because I was a careerist and bourgeois. Is this possible? (chuckle) So it was a horrible nightmare this Study in Russia camp. ${ }^{93}$

Then when I asked her about Communism and whether or not she became disillusioned with the ideology after the charges, she answered, "No, we thought that it was all a big mistake and not that the leadership or the ideology was flawed." She then digressed again. This time she told me about her life in the university and how it was only in 1953 when her opinions of the Communist Party began to change. Once she went into the countryside to help harvest the crops and seeing the extreme poverty she knew that something was wrong. ${ }^{94}$ Then, when Imre Nagy was forced to resign, "we realized that it is the upper leadership, the Rákosi and Farkas types that are to blame." She continued by explaining how she was a philosophy lecturer at the Eötvös Loránd University and Law University in 1956 (though she stressed that she did not belong to "the Lukács group" as György Lukács was too bourgeois.) Then, attempting to return to our original discussion, my colleague asked her what she thought about the szakérettségis period.

Inf. \#7: It opened up a lot to me. Afterwards I became a teacher. I taught them and there were excellent students. But there was disappointment too, I met with fewer personalities like I had before [in NÉKOSZ]. When I taught after 1956, it was terrible. They transferred me to an elementary school. It is especially terrible when a 
person goes from teaching in the university to an elementary school without any preparation. I had no idea what to do with children.

When I asked her why she was sent to the elementary school she explained,

Inf. \#7: The head of the department said to me "You can remain in the department if you break off all relationships with Domokos ${ }^{95}$ and your husband too, because they were associated with the counterrevolution." It was terrible that a woman with three children was expected to break off relations with her husband just to stay in the department ... so I said that I can't break off my relations with my husband ... Then they asked me my opinion of the present government. Well, at that time there was a common saying that went around, Kádár, Apró, Dögei. (laugh) [These are the last names of three leading Communists but when put together they also mean Kádár's puny carcasses.]

GM: And then you were transferred to an elementary school. (more laughter)

Throughout the interview we made several attempts to talk just about the topic of NÉKOSZ and the szakérettségis program but we never really succeeded. She wanted to tell us the whole story. To her, it did not make sense to separate the events - they belonged together. Everything, as she said, "flows together." In the end, we too lost interest in the original theme and had become engrossed in the events of her life. In a fitting article entitled "From Memory to History" Andrew Lass writes that, "the very act of reminiscing meant the possibility of explaining historically significant events in terms of their own "whereabouts." ple of the opposite; how historically significant events determined her whereabouts. History had shaped her identity. Agency was almost completely absent in her account. Everything she had become, or did not become, was determined by history. Because of "significant historical events" her father was killed, she became a teacher, she was prevented from studying in Russia, and she was sent to an elementary school.

Just as we were about to leave, she handed us the memoir of her year in the movement which she had written just after her husband had committed suicide. She said, "I wrote it then, and actually, I started writing the memoir under the impact of what I was feeling then, when my husband died. So, there will be references to the time or period when I started writing, [interruption] well, I don't know if you will like it, but then, it is not very interesting what I did, it is not very historical, but rather it gives the milieu of the period." 


\section{Pitfall III \\ History as Lacuna}

One major obstacle to oral history is that not everyone is willing to talk openly about their past; that is why oral historians must be extremely mindful of what is left unsaid. Despite numerous attempts, not one of the informants I met with wanted to discuss in any detail the role of Communist ideology in the movement. It was not something that they wanted to be reminded of, especially in Hungary's current political climate. Most simply stated it was not really essential to college life. And if they did confess to being a Communist, they always emphasized the fact that they were not Party Communists.

One informant, a well-respected representative of the Hungarian Socialist Party admitted that Communism did play a major role in the movement, but he emphasized, "not that Communism, but another type of Communist ideology which was far from the Communism of Rákosi. [The Communism of NÉKOSZ] resembled more what later became known as Euro-Communism than the Stalinism of the time." 97 Another informant, when asked about the role of Communist ideology in her people's college, said, "Yes, I came into contact with certain personalities who believed in Communism, but they were not that kind of Communists... 'Party soldiers' were not common in NÉKOSZ. I would say that a critical and rebellious attitude was more characteristic." 98 In both interviews, they assumed that I knew what they meant by that Communism. It was clear that they did not want to be associated with Rákosi and the Stalinism of the period, for that would have been tantamount to admitting that they were the pawns of the party, or an "army of janissaries," as the non-Communist press had put it at the time.

At least one of my informants was associated with that kind of Communism. Not only did he replace Kardos as first secretary of NÉKOSZ, but he also authored several articles - replete with Stalinist rhetoric - about reactionary elements in the movement (thereby confirming the party's criticisms) and the need to merge into the educational system of the state. So when I called to ask him for an interview, I expected to encounter some reluctance. And of course there was. After some discussion, he finally agreed to meet with me provided I would send him my questions prior to the interview, which I did. Of all the interviews, his was the most formal and, on the surface, least helpful. When I asked him about the political situation during the last year of NÉKOSZ, he skirted the question entirely and gave me a history lesson on Stalinism. After an hour of discussing the Soviet purges of the 1930's and the international events after World War II, he finally tried to explain his actions.

Inf. \#2: I was a very disciplined party member, who held certain characteristic NÉKOSZ beliefs, but the university reforms were made. 
They professionalized NÉKOSZ as they had planned. They took out the critical opposition from the movement. They started the nationalization process. The entire people's college was financed by state funds, and we convinced ourselves (I also was of this mind) that it was our task to take the NÉKOSZ experience and expand it to the entire Hungarian people's college system; to make it all the same. So, there would be a united state people's college system that would naturally be an institute of the state. Here you must see that the last year of NÉKOSZ the political purges occurred, the Rajk purges, this happened in NÉKOSZ too. There were expulsions for whatever reason ... but NÉKOSZ was an elite movement, and not a mass movement. An elite movement was extremely important for society, if you can save your autonomy. But it was impossible. It is as if every university in America would be Harvard. NÉKOSZ lost its importance once it gave up its autonomy.

Interviewer: When you became the First Secretary of NÉKOSZ, did you know that it would come to an end?

Int. \#2: Yes, just as I said, it would cease as an independent movement and be absorbed into a great unified people's college [system]. Now, afterwards, I also saw how manipulated I was, from what I read in the documents. ${ }^{99}$

One obvious characteristic of memory is that it is highly constructed. Even someone like the above informant who was a professed Stalinist can reinvent his past in such a way as to render himself a victim of the period.

\section{Mobility, Motivations, and Meaning}

While it is true that the interviews I conducted do not always fulfill the objective standards of traditional history, they can help us to better understand the motivations of the actors, or at least, provide us with a backdrop with which to view the period. What I discovered while interviewing some of the participants is that there was another aspect of this movement that was not only political, but social as well. At the heart of NÉKOSZ was the "beautiful dream," a truly modernist project whereby talented poor peasant students would be transformed into a progressive intelligentsia and serve as the harbingers of a new democratic social order. As Iván Vitányi, former collegian explained, "This is the revolution of NÉKOSZ, that these boys and girls from the villages were told that they were going to be the intelligentsia, and they did become the intelligentsia."100

I believe that this aspect distinguishes NÉKOSZ from other more bureaucratic transmission belt organizations. Not only did these students participate in politics, they also faced the psychological challenges of upward social mobility. Many left 
their villages and families behind, moved to the city, and literally re-invented themselves. Adapting to their new urban setting was for many the most difficult challenge. Some had never before sat in a car or seen an English toilet or used a toothbrush. According to one woman who grew up in the small community of Beled in Western Hungary, when the NÉKOSZ students convinced her to go to Budapest, the people in her village were shocked. They wondered "what will happen to me in the big city, they couldn't even conceptualize it, what will happen to me. It didn't matter that I would live in a people's college, it didn't matter that the people's college members promised to watch over me, they did not want to let me go. And a girl study? For what? Girls get married, and that's it." 101 When she first arrived at "bünös," [sinful/wicked] Budapest she recounted how difficult it was for her to adjust. "I cried more often than not, because I hated being down here so much. Gray, tall houses, and everything was in ruins due to the bombing. I hated it. I hated this city, and I sobbed." 102 Another participant who attended a secondary people's college in Budapest remembered that the adjustment was all the more difficult because her principal was unprepared to help them deal with the shock of city life. As they entered the people's college for the first time, they noticed that the principal had decorated the walls with dried corn and hot peppers in order to make them feel more at home. Of course this inaccurate depiction of peasant life only served as a further reminder of the gap between the two worlds.

Part and parcel of this modernist project was the belief that the people's college would bring culture to these talented peasants. According to the principal of the Dance and Choir people's college, the students "had to study more than other university students. Not only did they have to go to the theater and concerts, but there was also a quota of books that they were required to read and debate [in addition to their normal studies]. This was not easy, it was a burden that not everyone could handle." 103 In fact, it was a burden made all the more difficult because of their peasant origins and the lack of opportunity during their youth. In order to catch up and fit into their new intellectual environment, these students were put through intensive cultural instruction. According to one of the founding members, now a member of the National Cooperative Council, in addition to two foreign languages, and their normal university tasks, "every day there was a cultural task that we duly fulfilled ... You could say that we received a surrogate education, a substitute for what city kids could experience on their own, but we villagers could not. We attended every museum exhibition. There was also an opera course. We met once a month at the opera house and they acquainted us with one production. Of course they didn't just lecture to us, they also played a few arias, spoke about its history and told us why it was interesting. In this sense, there was an attempt to give the students the benefits enjoyed by a student from the city." 104 
When I asked one people's college member about how the peasants adapted to city life, she answered,

Very harshly. There was a serious case of decompression sickness, tunnel disease that broke out in me and other students, in part because of the city life, and in part because of my teachers. I wasn't forced to take just one leap, but fifteen! I met so many intellectuals for the very first time, and in such a society, one always strives to rise above and find one's place. This is tension. It was a very good thing but it came with enormous tension ... I must read this much, I should know this much ... Some people could handle it, some people could not. $^{105}$

But despite the many challenges of city life, the people I spoke with, and the large majority of members, did eventually adjust to their new surroundings. Many became professionals (doctors, professors, lawyers and teachers). Others attained leadership positions in the government or the Communist Party. One woman, who later became a radio producer, told me, "I am entirely sure that I would not have gone to the university if it hadn't been for NÉKOSZ. So to me, this meant my entire life. I met so many types of people I would never have been able to meet in the village. A great intelligentsia." 106 As for the women who for the first few months cried more often than not, she told me that she eventually came to love the city and people's college life. In fact, when she did visit her old village, a rare occurrence because she could not afford a train ticket, she confessed that she was no longer able to relate to her old friends. While they had gotten married and had children, she had shed much of her peasant past and had become a different person. ${ }^{107}$

There are many pitfalls in oral history. It is impossible to get an "objective" account of history, or even one that meets the standards of traditional history; inevitably something gets in the way. The first person I interviewed wanted to convince me that the NÉKOSZ pedagogical model was applicable in America. Whether intentional or not, she did not say anything negative about the movement even though not everything was as idyllic as she claimed; she was even expelled from her people's college. It is as if she adjusted her memory to reflect her youthful ideals. The second woman could not confine her story to the history of the movement. Perhaps she felt that NÉKOSZ had meaning only in relation to other events in her life; that they all "flowed together." Perhaps to her, the movement was incomprehensible when viewed independently. She wanted to tell the whole story. Finally, in the last section, the man I interviewed did not want to confide in me for obvious reasons. Now a well-respected scholar, who quit the Party in 1956, he did not want to reopen memories of a difficult period in his life, or implicate himself before the public. Thus, in all of these interviews, it was impossible to 
separate "fact" from "emotion" and manipulation, and construct a more objective narrative.

But it is this subjectivity that renders oral history so useful as a genre. Most importantly, oral history explores how meaning is constructed. Authoritative memories do not constitute closed discursive fields; they are always re-interpreted. The individual, in the process of remembering, picks and chooses what will be emphasized depending on personal experiences, intentional or unintentional lapses of memory, confabulations, and the individual's relation to the present. As individuals remember, emotions and values are emphasized and "facts" lose their meaning.

Near the end of my last interview, I asked the subject whether or not she felt that something was missing in the five-volume work? The rest of the discussion is telling.

Inf. \#8: Somehow, ah, I don't know, perhaps I should ask you the same question. As an outsider, when you finished reading them, did you get an authentic picture? Interviewer: I did and I didn't.

Inf. \#8: Yes, this I did and I didn't. Yes, I had the same problem. Too much material, unfiltered, not really aimed at anything. Among too many details, one loses the essence. I think that often.

Interviewer: Just what is the essence?

Inf. \#8: So many personalities, that it could influence so many different personalities. How can it be, to this you did not get an answer, how can it be that for so many people, after 40 or 50 years, it remained a fundamental experience. Did you get an answer to that question?

Interviewer: No. ${ }^{108}$

\section{Conclusion}

In this work, I have tried to focus on the micro-level events through the analysis of the network of people's colleges. The NÉKOSZ movement, operating in the trenches of Hungarian society, did maintain a link with the political forces above and even contributed to the Stalinization of the country. Nevertheless, the interview segments included in my work also demonstrate that politics was just one of many aspects of life in the people's college. They also present the reader with possible motivations behind the political activities of the collegians. As the oral historian Larry Holmes stated, "Oral history may tell more of what people wanted to achieve or what they believed they were doing rather than what they did." 109

In fact, the construction of meaning - part and parcel to the act of remembering - renders it difficult for oral historians to reach definitive conclusions as to the 
motivations of historical actors. In the end, we can only speculate about the true intentions of the collegians. On the one hand, it can be convincingly argued that these students were opportunists who gained personal advantage from the Communist transition in Hungary. No doubt, they were among the generation of young intellectuals who profited from the brief period of upward mobility ${ }^{110}$ and many went on to find jobs in the government and the Communist Party. However, it is possible to make just as compelling an argument that many of these men and women also acted out of conviction. The inequalities of the Horthy regime and its financial and moral collapse during the war made it easier for the Communist Party to manipulate segments of the population that would not, under normal circumstances, have been attracted to the tenets of Marxism-Leninism. Not only were these students afforded an opportunity for upward mobility, but they were also presented with an ideology of hope; a hope not afforded to them in interwar Hungarian society. As the widowed wife of László Kardos explained, "The father of one people's college student cried when he got land. Now that child whose father cried when he received five holds of land thereby realizing the dream of his great grandfather, how in the world would he not have become a Communist?" "11 Of course, many men who received land did not become Communists. We can only guess as to the intentions of the collegians that joined the Communist movement. No doubt, like other political actors who wittingly acquiesced in the will of the Communist Party, most of these students were unaware of what lay ahead. They did not realize that much of the allotted land would later be collectivized, nor did they foresee that freedom and democracy, as they understood it, was a "beautiful dream" that would not be fulfilled.

\section{Notes}

1. The village explorers were a group of populist writers and other academics who in the midthirties published ethnographical studies of village life in Hungary.

2. Pál Teleki (1879-1941) was a major political actor in interwar Hungary and a notable geographer as well. He was prime minister in 1920 and in 1941 when he committed suicide in protest of Hungary's participation in the attack on Yugoslavia.

3. The word népi can mean either "of the people" or "populist". The Hungarian word kollégium is rather ambiguous and has many meanings. The first definition in the Magyar Értelmezö Kéziszótár, and the most appropriate for this study, states that a kollégium is a dormitory that also provides its members with spiritual direction. This, too, is slightly misleading. Not only did the népi kollégiums provide students with spiritual direction, but they also made up selfcontained communities that functioned both in and outside the walls of the dormitory. It is also important to note that there were also elementary and lyceum people's colleges. Magyar Értelmezö Kéziszótár (1992), s.v. "kollégium."

4. Quoted in a paper written by Lajos Turczel in 1940 entitled "Szelekció és a Bolyai-kollégium" 
[Selection and the Bolyai People's College] found in the archives of Politikatörténeti Intézet [Political-Historical Institute] (PTI) 302.f.1/216.

5. The term "silent revolution" was coined in 1937 by the well known populist writer, Imre Kovács, who later became vice president of the National Peasant Party (1946-1947). Dózsa György was the leader of a large-scale peasant revolt in the early 16th century.

6. Initially, the Turul League required all incoming students to prove that both their parents and grandparents were of pure Hungarian blood. One informant recounted to me that this practice became a bone of contention between the Turul League and the people's college. Apparently one applicant, Juszkó József, was barred from the people's college by the Turul League because his name was Slavic. The collegians secretly accepted him into the group and this and other issues led to their break in 1942.

József Pál, Interview by author, 16 November 1999, interview 3, tape recording, personal collection.

7. Zsindely was introduced to the collegians through his wife, Klára Tüdős, an "ethnographic fanatic" who became good friends with the group in the 1930s while working at the Region and Folk Research Institute [Táj- és Népkutató Intézet].

8. The first March Front was established in 1937 by left-wing intellectuals, including Communists, in order to present Hungarian society with an alternative to both Fascism and Capitalism. For more information see, "Mit kíván a magyar nép: A Márciusi Front programja" [What the Hungarian People Want: the March Front Program.] Válasz [Answer] (June 1938), 121.

9. All of these men were active politically in the Communist Party after the war. Lajos Fehér went on to become one of the architects of Kádár's economic reforms (NEM), Sándor Zöld, who became the Minister of Interior in 1950, committed suicide during the Stalinist purges. Both Donáth and Losonczy filled important political positions in early 1950s - Donáth was the president of the Secretariat of Central Leadership, and Losonczy was head of the Szépirodalmi Kiadó [Literature Press] - when they were imprisoned during the Stalinist purges. Later, they played leading roles in the 1956 revolution. As a result, Losonczy died in prison before his trial in which he would have been put to death, and Donáth received a long prison sentence only to be released in 1960 .

10. In the course of a series of Sunday excursions in the Buda hills, a great deal of Marxist literature was made available to these students, such as the Schönstein notes, works of Lenin, the Dimitrov letter, and the influential article written by József Révai, under the pseudonym Sándor Vörös [Red], entitled "Marxizmus és népiesség" [Marxism and Populism]. The later is significant because it was the first positive overture of the Hungarian Communist Party to the Populist writers. For a detailed account of this see Lajos Fehér, Így történt [It Happened Like This] (Budapest: Magvetö, 1979), 145-149.

11. András Hegedűs explained in an interview that the Communist cell was "rather militant" and "to a certain degree" it "terrorized the rest of the group." In a 1986 interview Antal Gyenes, the first collegian to join the Communist Party, also admitted that the Communist cell manipulated the group. It was a "general law that an organized small group could impose its will on a larger heterogeneous group. The Fascists also were able to do this. It was a rather general rule. We knew what we wanted, and the collegians accepted it, in fact there were only two candidates, one who the Patrons [Pártfogók, i.e., the Institute of Patrons was a governmental organization led by Zsindely] would have wanted and our own candidate who already was a collegian ... It was clear that together the entire people's college voted for Kardos, the collegian." Antal Gyenes, interview by István Hegedűs, February 1986, 1956-os Intézet [The 1956 Institute], Budapest.

12. Democracy meant a number of things to the group. On the one hand, it meant that each member had the right to express his or her opinions publicly and the right to vote for the principal and other officials of the people's college. On the other hand, in contrast to liberal democracy, 
it also meant that individual needs often had to be sacrificed for the imperatives of the group.

13. See László Svéd, “A szervezett munkásifjúság politikai tevékenysége és részvétele a fegyveres ellenállásban (1939-1945)" [The Organized Political Activity and Participation of the Worker Youth in the Armed Resistance. (1939-1945)], in Magyarország 1944 [Hungary 1944] (Budapest: Nemzeti Könyvkiadó, 1994), 258. According to the article, over 500 people took part in the demonstration.

14. By then the Communist members were Antal Gyenes, Lajos Fehér, Ottó Tőkés, Gyula Sipos, András Hegedűs, Gábor Kerek, Ferenc Szücs, Sándor Filip, Barló Szabó Ödön, László Komló and most likely László Kardos too. According to the 1971 answers to the questionnaire, most of the other Györffy collegians sympathized with the movement during this time. PTI 302.f $1 / 284$.

15. Although the Népszava was the organ of the Social Democrats, many of its editors and contributors were Communists. See Lajos Fehér, Így történt [It Happened Like This] (Budapest: Magvető, 1979), 136.

16. For a good account of this conference and the Györffy People's College's part in it, see Szárszó 1943, (Kossuth: Budapest, 1983) and Györffy Sándor, "Szárszótól Szárszóig, 1943-1993” in A népi mozgalom és a magyar társadalom [The Populist Movement and Hungarian Society] (Budapest: Napvilág, 1997) Kardos' quote taken from former p. 232.

17. Gyenes interview.

18. In the case of Antal Gyenes, Ferenc Zsindely and Fisher-Keresztes eventually negotiated for his release after he was tortured and spent several months in prison. Other students, like András Hegedűs actually escaped while being transported to a prison workshop. See András Hegedús, A történelem és a hatalom igézetében [In the Enchantment of History and Power], (Budapest: Kossuth, 1988), 72-76.

19. One of the collegians was even shot and killed by the Arrow Cross in the closing months of the war. Out of the fifty or so students, 20 received Hungarian Freedom Virtue awards from the Hungarian government, see Fényes Szelek Nemzedéke 354.

20. This was part and parcel of the Communist Party's Popular Front tactics whereby the Party sought to create a united front, or the illusion of a united front, and at the same time infiltrate the other parties with crypto-Communists, i.e., those members of the Communist Party who hid their party allegiance and joined other parties. For an account of this particular organization see Hegedüs 72, and the interviews of Antal Gyenes and Sándor Györffy. According to Sándor Györffy, the organization did function in a popular front manner until the non-Communist members left the organization. Hegedús also emphasized that the organization remained democratic until György Nonn was sent by the party in 1947 to create a more hierarchical institution. Hegedús interview 90. I believe a strong Communist influence was present in the organization from the outset and that is why youth leaders from other parties eventually left the organization and formed their own youth movements.

21. In the interest of creating an image of a popular front, the Communist leadership encouraged many collegians to join the National Peasant Party instead of the Communist Party. In his interview, Antal Gyenes states, "Naturally in the life of every Györffy collegian, he or she came into contact with Communist ideas, ideology, viewpoints and the process of becoming a Communist, at the same time, in the interest of legality we often had to deny this fact in front of the outside world, our organization and even between each other. This process continued even after the war as well, when most likely 70 percent of the collegians were members of the Communist Party. Révai nevertheless, was right to slow down our entrance into the party." Antal Gyenes, interview by István Hegedús, Budapest, Feb. 1986, 1956-os Intézet [The 1956 Institute]. 
22. Fényes Szelek Nemzedéke 364. Corroborating Gyenes' account, Sándor Györffy, who joined the Peasant Party as a crypto-Communist, stated that, "there was an agreement between Kardos and Révai, and perhaps Sipos was also involved. In other words, [Révai and] the two people's college principals made an agreement that the majority of Györffy collegians would join the National Peasant Party, because it was important then that the Communist Party have an ally in the National Committee." Interview conducted by István Hegedûs April 1988 found in the archives of the 1956 Institute.

23. András Hegedüs, interview by Zoltán Zsille, in Élet egy eszme árnyékában [Life in the Shadow of an Idea] (Budapest, 1989), 79. In hindsight, it is now known that the quick and comprehensive land reform program, ostensibly championed by the National Peasant Party, was decreed without debate in parliament at the insistence of Marshal Voroshilov, head of the Allied Control Committee, as a temporary tactic to gain public sympathy for the war that was still being waged in the western part of the country and to gain mass support for the Communists.

24. József Pál, Interview by author, 16 November 1999, interview 3, tape recording, personal collection.

25. Élet egy eszme árnyékában, 79-80.

26. For the complete article see Fényes Szelek Nemzedéke 517-518.

27. This account seems to me to be the most convincing. Unfortunately, I could not find evidence to corroborate or dispute her testimony. Interview \#4, interview by author, 17 November 1999, tape recording. personal collection.

28. In the elementary and lyceum people's colleges a teacher was chosen to be principal by the central leadership and was not selected by the collegians themselves. This work will focus on the university people's colleges because they were more actively involved in the day-to-day decisions of life in the people's college and took part in politics on a national level. According to the people I interviewed who attended a lyceum, besides the singing of revolutionary songs and occasionally marching in demonstrations, they did not participate in political activities. Still, the internal structure, i.e., student-run cooperatives and the népibiró, was the same.

29. Antal Gyenes stated that the emotional strength of the practice was so great that some of the serious collegians would "stand up and tear off their clothes like religious Jews at the burial of the dead." Interview 1986.

30. For some pros and cons see Fényes Szelek Nemzedéke 1192-1196; 1454-1472.

31. The only reading list that I could find in the archives was from the 1948-49 academic year. The vast majority of the works on the list were written by Marxists, among them were fourteen works by Marx and Engels, ten works by Lenin, five by the Hungarian philosopher György Lukács, four by Josef Stalin, and three by the Hungarian Communist leader Mátyás Rákosi. PTI 302.f.1/173.

32. No one to my knowledge has analyzed the emotive role played by the repetition of singing political songs and the contribution it made to the strengthening of Communist ideology. In the people's college, this type of propaganda attained a populist flavor and was central to the formation of collegian identity. The memoirs of one student of worker pedigree reads, "Around 8 o'clock everyone gathered to sing, usually this was accompanied by folk song lessons. They even explained the contents and type of songs they were. My first experience with this group folk lesson came as quite a shock ... There were singers who believed in Kodály['s emphasis on folk traditions] who came and taught us folk songs and other singers as well. Perhaps [it was a shock] because it was the first time that I had experienced adults, or near adults, take folk songs so seriously. They were so aware of the contents, the melodies. I would say that these evenings of folk singing developed a cohesion between us, and the sense that we are the people. All of these folk songs were taken from our native land and we learned the songs. We also sang revolutionary songs ... All of us believed in the contents of [the NÉKOSZ anthem] "Hey, 
our banner blows ..." It would have given strength to our rags and poverty had we not believed in the future." Gabriella Ösz's unpublished memoirs. See the text of the NÉKOSZ anthem at the beginning of Section I in this work, esp. the last line, "For tomorrow we will overturn the entire world!"

33. For example, the Zalka Máté People's college list of speakers for the 1947-48 academic year included such figures as Géza Hegedűs, Ferenc Erdei, József Darvas, Miklós Vásárhelyi, András Hegedüs, and Aladár Mód. Fényes Szelek Nemzedéke 1048-1050.

34. The account was found in the memoirs of Gabriella Ösz.

35. Some of the questions asked in the summer of 1946 were, "Can you go to hell if you swear?"; "What do you know about the populist writers?"; "What is a reactionary priest?"; "Who are the Communists and what do they want?" Fényes Szelek Nemzedéke 943-944.

36. László Svéd, Megforgatott Világmegforgatók [World Overturners Overturned] (Budapest: Political-Historical Institute, 1994) 74.

37. Sándor Pető's diary entry PTI 302.f.1/184. The Four Hundred Year Struggle for Independence was written by the Hungarian Communist Aladár Mód.

38. This seems to be the exception rather than the rule, especially with people's colleges located in Budapest and other major urban centers. According to several of the people I interviewed, the degree of Communist dogmatism varied extensively from college to college.

39. István Bibó, "Értelmiség és szakszerüség" [Intelligentsia and Professionalism], Demokratikus Magyarország, (Budapest: Magvető, 1994), 341.

40. Ignác Romsics, Magyarország története a XX. században [The History of Hungary in the 20th Century] (Budapest: Osiris, 1999), 321.

41. There are some exceptions. For instance, as we shall see later, Gyula Sipos risked his position on the editorial board of the journal Uj Hang [New Voice] because of his participation in the distribution of a memorandum on the re-establishment of NÉKOSZ. That is, after it had already been liquidated by the Hungarian Communist Party.

42. According to the NÉKOSZ statistical survey conducted in March 1948, 37.8\% of the officials (principals, dormitory supervisors [nevelötanárok], and secretaries) were members of the Communist Party, 25\% were members of the National Peasant Party, and 20.5\% were not members of any party, $8 \%$ were members of the Social Democratic Party and the remaining $8 \%$ was unknown. Moreover, $73 \%$ of the student body was not affiliated with any party. In what appears to be a stark contrast, the survey taken in September 1948 states that 140 of the 180 principals and dormitory supervisors [nevelötanárok] were members of the Communist Party. In the period when the second survey was taken, the NÉKOSZ leadership wanted to prove its Communist credentials. However, the disparity between the two surveys is not as great if we consider that the National Peasant Party was little more than a sister party to the Communist Party, the members of the non-affiliated leadership were likely to be sympathetic to the Communist Party, and that the second survey does not take secretaries into account.

43. The prime minister of Hungary at the time was Ferenc Nagy of the Smallholders Party.

44. It is revealing that in the November 1946 exam entitled, "Who are the enemies of the people?" the Györffy collegians consistently labeled reactionaries, kulaks, priests/church, capitalists, bourgeoisie, the Smallholders Party, and those Social Democratic and Peasant Party politicians, like Károly Peyer and Imre Kovács, who did not acquiesce in the demands of the Communist Party as being the enemies of the people. PTI 302.f.1/40 ö.e.

45. On the similarities, he wrote that "we [also] agree that the lengthy oppression of the Hungarian peasantry and workers is a crime. No matter what the cost, we should not shrink from bringing them to power and we should give compensation for the past twenty years of anti-peasant, antiworker political and economic discrimination.” Megforgatott Világmegforgatók 199. 
46. MAKE was established in September 1946 by the Smallholders Party, and DOKOSZ was established in May of 1947. Megforgatott Világmegforgatók 178.

47. This further strengthens the argument that the movement was under the influence of the Communist Party more than has been previously admitted. Unlike NÉKOSZ, these alternative people's college movements were unable to secure the financial resources necessary to operate effectively. Although there are very few available documents that describe how the movement was funded, it is reasonable to conclude that the Hungarian Communist Party financed the movement. The Hungarian Communist Party, by virtue of its relationship to Soviet officials and the Supreme Economic Council had access to a huge supply of funds. According to published documents, only one quarter of the five million five hundred thousand forint budget of 1946-47 came from state coffers and almost half the budget was financed by so-called "public support." The Hungarian Communist Party was the only party with the capital to finance such a large operation. For information on the NÉKOSZ budget see Fényes Szelek Nemzedéke 688 and for a list of companies that supported the Zalka Máté People's College see page 1020.

48. It is difficult to establish from the available documents how this merger actually transpired. In the case of DOKOSZ it appears that negotiations were held between Révai and Social Democrat representatives and it was up to Zoltán Vas, as head of the Supreme Economic Council, to approve the transfer of state funds to DOKOSZ: Apparently this did not happen and the Social Democrats were forced, due to lack of financial resources, to give up their people's colleges. See Megforgatott Világmegforgatók 193.

49. For example, according to the principal of the Zalka people's college, the collegians were "not normal university students" as "60 percent took part in youth politics [ifjúságpolitikában]" in the school year of 1947-1948. Fényes Szelek Nemzedéke 1132-1133.

50. Arendt writes, "For the front organizations of sympathizers are not less essential to the functioning of the movement than its actual membership. The front organizations surround the movements' membership with a protective wall which separates them from the outside world, normal world; at the same time, they form a bridge back into normalcy, without which the members in the pre-power stage would feel too sharply the differences between their beliefs and those of normal people, between the lying fictitiousness of their own and the reality of the normal world. The ingeniousness of this device during the movements' struggle for power is that the front organizations not only isolate the members but offer them a semblance of outside normalcy which wards off the impact of true reality more effectively than mere indoctrination." Hannah Arendt, The Origins of Totalitarianism (New York: Harvest Book, 1973) 366.

51. József Molnár, "Nyílt levél az iskolák államosítása ügyében” [Open Letter on the Nationalization of Schools], in Népi Kollégista [People's Collegian] (1948) June 4, no. 164, 1.

52. By the last year, the journals were completely Stalinized. For example on March 9th, 1949 the Népi Kollégista published this note, "Dear Comrade Mátyás Rákosi, Budapest. NÉKOSZ would like to express its warm thanks to Mátyás Rákosi on the occasion of his 57th birthday. Comrade Rákosi's foresight has shown our movement the proper path and life, the example of his battles teaches us and raises our collegians for self-sacrificing work. We hope that he leads our people on the victorious path to the building of socialism for decades to come. The NÉKOSZ Leadership." Népi Kollégista, (1949) April, 3. See also, "Épül a Szovjetunió", "Ilyen a Szovjet Munkásifjúság”, "Mátyás Rákosi: Építjük a nép országát”, "Éljen a Szovjetunió ifjúsága! A Komszomol dalai", "A kommunista nevelésről", "Stalin: Lenin élt, Lenin”, "Pavlenko: Boldogság" in Népi Kollégista (1948-1949) and "Makarenko a fegyelemröl" and "Részlet Makarenko "Új ember kovácsa' című könyvből” from Március Tizenötödike.

53. The "janissary" label was applied to the collegians on a number of occasions. The term was first used by Béla László in connection with the Györffy István People's College in his Sep- 
tember 1942 article "Should we raise the peasantry for the lords?" [Neveljen-e a parasztság uraknak?] and Gyula Illyés in his article "Heroes and Janissaries." [Hösök és janicsárok] In their articles both authors warned the collegians against becoming the "janissaries of the middle class.” see Fényes Szelek, 129-130. Then, in August 1946, Halassy Nagy József attacked the collegians for being the janissaries of the Communist Party. ibid., 580-581. After a speech given by Sándor Karácsony, a NÉKOSZ teacher, in January 1947, a person from the crowd accused the people's colleges of raising janissaries. ibid., 698. Finally, the label was well used by the Communist Party during the show trials. This time the collegians were labeled the "the janissaries of Tito."

54. It is revealing that religion and Communism are compatible to Petö. In other excerpts, he admits that he is religious, but opposed to reactionary priests. In one such entry, his own godmother would not let her daughter visit him because he accused one priest of being a reactionary and refused to kiss his hand. Petö writes how he still believes in God but does not respect some priests. Later, in a letter to Kardos, Pető defends his sister's choice to join the nunnery. PTI 302.1/184

55. Note: this is the same person who had the portrait of Horthy on his office wall.

56. Other "Communist" projects were more successful. NÉKOSZ developed strong relationships with neighboring Communist movements, especially with the partisans in Yugoslavia. In 1947, NÉKOSZ organized a Vasvári Brigade of over one hundred collegians and sent them to Vojvodina to assist the partisans in the rebuilding of their railroads. Perhaps as a token of his gratitude, Tito spent time with the Györffy collegians during his 1947 visit to Hungary.

57. Train-like public transportation that takes passengers to and from the suburbs of Budapest.

58. Ibid. 1135. The person is most likely referring to the 1947 national election.

59. Kardos' recollections quoted in Fényes Szelek Nemzedéke 1245.

60. Mihály Farkas and József Révai were among the four most powerful Hungarian Communist leaders at the time. Farkas was the infamous secretary of the Ministry of Interior who was held responsible for marshalling the police in support of the Communist Party. Révai directed the press, propaganda, and intelligentsia of the Communist Party.

61. It was not uncommon for people to be awarded a prize or promotion and then arrested for activities against the state. The same thing happened to Rajk before he was executed as a Titoist-American spy.

62. Judging from the summer schedule and the required reading list, it is clear that the NÉKOSZ leadership took the criticisms of the Communist Party seriously. All of the reading sources were written by Marxists, the vast majority being works by Marx, Engels, Lenin and Stalin. (21 out of 40) PTI 302.f.1/63.

63. György Lukács, “A fordulat problémái” [The Problems of the Transition] Fiatal Magyarország. June 28, 1948.

64. Fényes Szelek Nemzedéke 1259.

65. According to Iván Vitányi, Antal Gyenes had approached Kardos the day before and said, "Be prepared, tomorrow we will expel you.” Iván Vitányi, Interview by author, 18 November 1999 , tape recording, personal collection.

66. Svéd 244.

67. Although it is not in the scope of this work to analyze how ideology and pragmatism coexisted in the minds of the Communist leaders, both György Lukács's and József Révai’s speeches represent how ideological criticisms were often orchestrated for practical aims during the Stalinist period. [emphasis mine] Fényes Szelek Nemzedéke 1270.

68. Kálmán Rem's diary entry from the Lajos Kossuth People’s college in Miskolc. PTI 302.f. $1 / 99$ 
69. Fényes Szelek Nemzedéke 1324.

70. According to the testimony of both Béla Korondy and Dr. Tibor Szőnyi, Rajk, as an American and Yugoslavian agent, wanted to use NÉKOSZ to raise a partisan army of kulaks to rebel against the state. László Rajk and his Accomplices Before the People's Court. (Budapest 1949), 157 and 183.

71. The szakérettségis was an educational program created at a time when the Communist Party needed cadres. The program, which replaced the people's college movement starting in 1949 , granted high school diplomas and university admittance to students (mostly workers) after the completion of one to two years of study. For more information on this movement see Mária Kovács and Antal Örkény, Káderek (ELTE Szociológia és Szoc-politikai Intézet: Budapest, 1991).

72. Arendt 323.

73. "Fiatal írók memoranduma." For a complete copy of the memo see Megforgatott Világmegforgatók 340-354.

74. The Petöfi Circle was a group of intellectuals who sponsored a series of controversial debates in 1956. These debates, attended by such figures as György Lukács and the former president of Hungary, Ferenc Tildy, were partly responsible for radicalizing the intellectual opposition that led to the revolution. See György Litván, The Hungarian Revolution of 1956 (London: Longman, 1997), 39-41

75. Erwin Hollós, Secretary of the Democratic Youth League, issued the statement in Szabad Nép [Free People] the official daily of the Hungarian Communist Party. For an excerpt of that article see Fényes Szelek Nemzedéke 1374-1375.

76. See Megforgatott Világmegforgatók 389-402 and “A Politikai Bizottság határozata...” Szabad Nép September $16^{\text {th }}$.

77. Literally, the Communist Party asked Hegedús on the $26^{\text {th }}$ to write a letter requesting military assistance that was predated to the $23 \mathrm{rd}$ when he was still prime minister of the country. This letter was used to justify ex post facto the Soviet occupation of the country.

78. Kardos was lucky to receive only six years. Originally Nagy had wanted to name him Minister of Culture, but Hegedüs convinced him to stick with Lukács. Gyenes was even luckier. He was appointed Minister of Appropriations but was stricken with an illness, taken to the hospital and never got the chance to fill his post. He literally slept through the revolutionary events. Hegedüs 309.

79. György Aczél was one of the most influential politicians of the Kádár period. During the time in question, Aczél was the man responsible for shaping cultural life in Hungary.

80. Interview \#1, interview by author, 14 November 1999, tape recording, personal collection.

81. In fact, in 1969 Aczél gave permission to publish an article entitled, "László Rajk és a népi kollégiumok" [László Rajk and the People's Colleges] as a tribute to Rajk and the movement but the article never saw print because of a conflict between Rajk's widow and Aladár Mód, one of the contributers. Levente Sipos, "Kardos László visszaemlékezése Rajk László és a népi kollégiumok kapcsolatára." Múltunk (1993), no. 3, 234.

82. Fényes Szelek Nemzedéke 11.

83. All but one of the persons I interviewed told me that they do not attend these meetings. Either they did not agree with the group's politics, did not have faith that anything good will come out of the meetings, or simply did not want to participate in "remembering the olden days, just like a high school reunion" or adopting the attitude of "old nostalgic men, the "Oh, how good it was' attitude." Interview \#4, interview by author, 17 November 1999, tape recording, personal collection. Interview \#8, interview by author, 22 November 1999, tape recording, personal collection. 
84. Budapest Conference, 11 November 1999, tape recording, personal collection. (Ironically, the speaker's name does not come out clearly on the tape.)

85. Interview \#7, interview by author, 17 November 1999, tape recording, personal collection.

86. A történelem és a hatalom igézetében 6.

87. The Fényes Szelek Nemzedéke work included a number of articles and speeches by leading public figures, like Cardinal Mindszenty, who accused the movement of only accepting those students who have Communist leanings.

88. Interview \#1, interview by author, 14 November 1999, tape recording, personal collection.

89. Interview \#4, interview by author, 17 November 1999, tape recording, personal collection.

90. Because my friend, György Majtényi, is researching the szakérettségis program, I invited him to participate in the interview. For a brief description of the program see footnote 79.

91. She is referring to Gábor Tánczos' survey published in the 1970s. Gábor Tánczos A kollégisták útja 1939-1971 [The path of the collegians 1939-1971] (Budapest: Központi Statisztikai Hivatal, 1976).

92. Interview \#7, interview by author, 22 November 1999, tape recording, personal collection.

93. She was sent to the Russian Study Camp well after the fall of NÉKOSZ.

94. According to her account, the harvesters were so poor that after they had finished their work, three men shared the two sparrows they had shot earlier in the day.

95. Most likely, she is referring to the historian Kosáry Domokos who sympathized with the revolutionaries.

96. Andrew Lass. "From History to Memory." in Memory, History, and Opposition under State Socialism. ed. Rubie Watson (New Mexico: School of American Research, 1992) 93.

97. Interview \#5, interview by author, 19 November 1999, tape recording, personal collection.

98. Interview \#8, interview by author, 22 November 1999, tape recording, personal collection.

99. He is referring to the Stalinist speeches he made during 1948-1949 that were published in the five-volume collection. Interview by author, 16 November 1999, interview 2, tape recording, personal collection.

100. Interview \#5, interview by author, 19 November 1999, tape recording, personal collection.

101. Interview by author, 22 November 1999, interview 6, tape recording, personal collection.

102. Unfortunately, I was only able to meet with those former collegians that had attended people's colleges in Budapest. The people's colleges in Budapest were the most influential and made up about one-third of all the people's colleges and more than half of the university people's colleges. It should also be added that not every collegian was unaccustomed to city life. Sons and daughters of the "progressive" intelligentsia and workers were also accepted into the people's college, especially in the final year (roughly 30\% of the student body), see Tánczos 19 .

103. Interview \#5, interview by author, 18 November 1999, tape recording, personal collection.

104. Interview \#3, interview by author, 16 November 1999, tape recording, personal collection.

105. Interview \#8, interview by author, 22 November 1999, tape recording, personal collection.

106. Ibid.

107. Interview \#6, interview by author, 22 November 1999, tape recording, personal collection.

108. Interview \#6, interview by author, 22 November 1999, tape recording, personal collection.

109. Larry E. Holmes. "The Oral Record and Moscow's Model School No. 25, 1931-1937." Slavic Review vol. 56 no. 2 (Summer 1997) 285.

110. See Antal Örkény. "Social Mobility and the New Elite in Hungary." Social Structure, Stratification and Mobility in Central and Eastern Europe, ed. Rudolf Andorka and Miklós Hada (Budapest: Soros Alapítvány, 1990) 257-267.

111. Interview \#4, interview by author, 17 November 1999, tape recording, personal collection. 
